\title{
Growth Performance of Abaca (Musa textilis Née) Integrated in Multi-strata Agroecosystems
}

\author{
Marlito M. Bande ${ }^{1,3}$, Victor B. Asio², Joachim Sauerborn ${ }^{3}$, and \\ Volker Römheld ${ }^{4}$
}

${ }^{1}$ Institute of Tropical Ecology and Environmental Management, and ${ }^{2}$ Department of Soil Science, Visayas State University, Baybay City, Leyte, Philippines; ${ }^{3}$ Institute of Plant Production and Agroecology in the Tropics and Subtropics, and ${ }^{4}$ Institute of Plant Nutrition, University of Hohenheim, Stuttgart, Germany

\section{ABSTRACT}

Abaca is a shade loving crop with a good potential to be integrated into agroforestry systems that offer sources of income and prevent soil erosion. However, in integrating abaca into multi-strata agroecosystems, one has to consider radiation interception and the efficiency with which radiation energy is used to produce photosynthates since these play a crucial role in the growth of tree-crop stands. Hence, this study investigated the best shade plant-abaca combination and its influence on light transmission ratio in relation to the abaca's morphological growth performance. The results revealed that the light intensity under the canopy shade of coconuts is sufficient for the growth of abaca plants. On the other hand, Rainforestation (the planting of native tree species to rehabilitate degraded lands) appeared to be an effective approach in restoring the functions of an abaca-based agroecosystem by improving soil quality suitable for the crop. Therefore, the tree-abaca under the Rainforestation system was the best combination. However, the sustainability of both production systems always lies on the hands of the farmers, either to cut or harvest the trees or old coconut palms for lumber or to preserve them for ecological purposes by providing shade and wind breaks for the abaca plants. Finally, due to high planting density in both types of abaca-based agroecosystems, fertilizer application and the use of high quality planting materials are highly recommended. Likewise, topography and exposure to strong winds should be considered during site selection prior to abaca-based production system development.

Keywords: abaca, agroecosystem, rainforestation, irradiance, shade crop

\section{INTRODUCTION}

Abaca is closely related to edible banana and is grown primarily for its fiber (Bande et al., 2013a) that is indigenous to the understorey of the Philippines' tropical lowland evergreen rainforests (Tabora Jr., 1978; Halos, 2008; Sievert, 2009). Abaca grows best on a fertile soil of recent volcanic or alluvial origin with good moisture retention (Spencer, 1953; Umali and Brewbaker, 1956; Tabora Jr. and Santos, 1978), rainfall of $2000-3000 \mathrm{~mm}^{-1}$ year , no dry season, humidity 
range of $78-88 \%$, optimum temperature range of $20-27{ }^{\circ} \mathrm{C}$ (Halos, 2008), and at altitudes up to 1000 meters (Sievert, 2009).

Abaca plants can be propagated by seeds or by vegetative cloning (i.e., sucker, corm or seed pieces, eyebud, or tissue culture). Propagation by seeds was practiced in earlier times but is no longer used because seeds do not reproduce true to type and are used only for breeding work (Halos, 2008). Vegetative cloning or propagation is widely adopted (Sievert, 2009). Suckers at least one meter in height with a well-developed root system have been used traditionally and are best for replanting of old plantations.

In developing an abaca farm, the recommended distance of planting is $2 \mathrm{~m} \mathrm{x}$ $2 \mathrm{~m}$ for smaller varieties and $2.5 \mathrm{~m} \times 3.0 \mathrm{~m}$ for larger varieties whether using suckers, seed pieces, or tissue cultured seedlings as planting materials (FIDA, 2010). The site should include some shade trees, especially important for protecting the young plants from the sun and the older, taller plants from wind breakage (Bande et al., 2013b). Leguminous trees are highly recommended because they do not only provide shade but also enrich the soil with nitrogen through symbiotic relationship with soil bacteria (Bande et al., 2012). Abaca planted as a monocrop gives a significantly lower yield than those planted with annuals intercropped, e.g.. legumes and cereals (Moreno, 1994). It takes 18-24 months (in fertile forestland) and 24-30 months (in open places with continuous cropping) before abaca can be harvested (Halos, 2008).

Abaca is a shade-loving crop with a good potential to be integrated into agroforestry systems (Lacuna-Richman, 2002, Bande et al., 2013a, Bande et al., 2013b) that offer sources of income (Dargantes, 1996) and prevent soil erosion (DENR, 1997). On Leyte Island, abaca-based agroecosystems are concentrated in mountainous areas where abaca is usually planted in the shade beneath tall trees or coconuts (Armecin and Gabon, 2008). Intensive abaca cultivation in these areas has been done for years without applying any fertilizer as supplement to the crop (Lacuna-Richman, 2002).

In integrating abaca into multi-strata agroforestry systems, one has to consider radiation interception and the efficiency with which radiation energy is used to produce photosynthates since these play a crucial role in the growth of tree-crop stands (Balster and Marshall, 2000; Will et al., 2001; Allen et al., 2004; Kemanian et al., 2004). Normally shading reduces photosynthesis, transpiration, and partitioning of biomass from vegetative parts to economic parts (e.g. Akhter et al., 2009). However, morphological and physiological adaptations tend to take place in response to variation in solar radiation in order to maintain maximum photosynthetic efficiency of the leaves (Duriyaprapan and Britten, 1982). A number of studies have shown that any kind of shading reduces productivity (Copeland, 1911; Strover, 1984; Israeli et al., 1994; Stanhill and Cohen, 2001; Akhter et al., 2009), while others have found that crop productivity increases under moderate shade (Boardman, 1977; Björkman and Holmgren, 1966; Holmgren, 1968; Batugal, 1977; Raveh et al., 2003; Isaac et al., 2007; Saifuddin et al., 2010). However, Batugal et al. (1977) documented that improved abaca (variety Tinawagang puti) plant growth was observed under partial shading at 33\% and $66 \%$ than in open space. Armecin et al. (2011) reported that in coconut-abaca cropping system, abaca growth was suppressed not only due to exhaustive belowground (nutrient) but also aboveground (light) competition. Therefore, this study was conducted to 
investigate the best shade plant-abaca combinations (i.e., coconut-abaca and treeabaca) and its influence on light transmission ratio in relation to the abaca's morphological growth performance.

\section{MATERIALS AND METHODS}

\section{Location and Climatic Condition of the Study Sites}

Two study sites were established at two different areas near Baybay, Leyte, Philippines. The first site (Barangay Caridad) is located about $14 \mathrm{~km}$ northeast of Baybay town at an elevation of 122 asl. The second site (Barangay Mailhi) is about $23 \mathrm{~km}$ southwest of Baybay at 351 asl elevation. The climatic data were collected from the Philippine Atmospheric, Geophysical and Astronomical Services Administration (PAGASA) weather station at the Visayas State University. Average daily air temperature was between $27^{\circ} \mathrm{C}$ and $28^{\circ} \mathrm{C}$ while average annual temperature was $27.3^{\circ} \mathrm{C}$ during the time of the research which is within the range of the long-term average of Leyte. The average incident rainfall was $2218 \mathrm{~mm}$ during the conduct of the study.

\section{Biophysical Examination of the Study Sites}

The two research sites are comparable in terms of soil physiography and geology (Asio, 1996). This was accomplished by a very detailed survey using auger to make sure that the soils were comparably similar as indicated for example, by morphological features such as color, texture and horizonation. Similarly, three pits (1 meter wide and $1.2 \mathrm{~m}$ depth) per study site were excavated for soil profile examination, description, and classification according to FAO guidelines (Jahn $e t$ al., 2006) and the World Reference Base (IUSS Working Group WRB, 2006).

The first site is presently a 40 -year old monoculture coconut plantation and with a declining productivity which is one of the major considerations for the site selection. The soil is classified a Haplic Alisol (IUSS Working Group WRB, 2006) whose clay fraction is dominated by kaolinite and halloysite and contains significant amounts of goethite and hematite with more than $60 \% \mathrm{P}$ retention capacity (Asio, 1996; Asio et al., 1998). Likewise, the site 1 soil is characterized by $\mathrm{Ah}-\mathrm{Bw}-\mathrm{Bt}_{1}-\mathrm{Bt}_{2}-\mathrm{Bt}_{3}$ horizon sequence to a depth of 1 meter. This indicates an accumulation of silicate clay that has formed in the horizon or has moved into it by illuviation or either both. The $\mathrm{pH}$ indicates strongly acid conditions (Soil Conservation Society of America, 1982) and there is a slight tendency for $\mathrm{pH}$ to increase with depth.

On the other hand, the second site is originally a 10 -year old Rainforestation farm. Under the Rainforestation production system, fast growing (pioneer) native species were planted first with successional species and then with late successional species (dipterocarps) and fruit trees in the subsequent year. The site was selected since harvesting of pioneer tree species is already possible, and harvesting will improve the light illumination for the understory dipterocarp and fruit tree species and site suitability for abaca. The soil is classified a Siltic Andosol (IUSS Working Group WRB, 2006), having a texture of silty clay loam or silty clay in a layer, $30 \mathrm{~cm}$ of the soil surface. The acid weathering of other silicate-rich material resulted to 
the formation of stable organo-mineral complexes (Asio, 1996; Asio et al., 1998). The soil in this site is characterized by an $\mathrm{Ah}-\mathrm{Bw}_{1}-\mathrm{Bw}_{2}-\mathrm{Bw}_{3}$ horizon sequence with the solum reaching a depth of 1 meter. The $\mathrm{pH}$ values indicate strongly acid conditions (Soil Conservation Society of America, 1982) but $\mathrm{pH}$ decreases with depth.

\section{Site Establishment and Planting Design}

During the study site establishment, two abaca varieties (laylay and inusa) were used based on site suitability, disease resistance, yield, fiber tensile strength, and farmer's preference. In site 1 , a total of 40 quadrant plots were established with each plot of an area of $100 \mathrm{~m}^{2}$ and planted to 25 abaca suckers. Quadrant design was used since slope exposition was more or less homogenous and there was a wide planting distance between coconut trees. Moreover, the site was divided into different blocks based on topography, vegetation cover and species composition. The intention was to consider each block as one treatment and the plots that belong to a particular block correspond as repetitions to the treatment. Thus, site 1 was divided into 5 blocks with 7 plots each block, except block 5 which had 12 plots.

In site 2, the area was divided into four different blocks mainly because of heterogeneity of the slope and undefined planting distance between trees. Thus, a circular design was used. A total of 5 circular plots were established per block. Each plot had an area of $180 \mathrm{~m}^{2}$ and planted with 50 abaca suckers. Furthermore, each block was considered as one treatment and each plot that belonged to a particular block was treated as repetition to the treatment. To reduce variability for result comparisons between the sites, each site had an area of at least 1 hectare.

\section{DataCollection}

Monthly growth performance was monitored in the two study sites for the period September 2003 until April 2004. The following were measured: (1) site specific measurements on solar radiation and temperature; (2) canopy structure and light interception that included measurements of light in canopies of individual plants in each plot by using a light sensor, leaf area index by using the area-length regressions (Kvet and Marshall, 1971 and adopted by Coombs, 1985), and number and life-span of the leaves from the date of appearance to date of senescence; and (3) plant growth performance by measuring the total plant height and base diameter using a meter stick and diameter tape, respectively.

\section{Statistical Analyses}

All data were tested for normality and homogeneity using PROC Univariate of Statistical Analysis System version 9.1 (SAS, 2003). PROC GLM (general linear model) procedure was initially performed to check for the influence of agroecological production systems and its light transmission on abaca plant's morphological traits. The final models for each response variable were analyzed 
but including only those significant main factors effect for each agroecosystems. Duncan multiple range test (DMRT) and least squares differences (LSD) were carried out to compare means of independent variables with significant variations at $\mathrm{p} \leq 0.05$.

\section{RESULTS AND DISCUSSION}

\section{Light infiltration in different multi-strata agroecosytems}

About half of the energy received at the top of a plant canopy arrives as visible light. Leaves used absorbed light to fix carbon dioxide and create the substance of the plant. This together with the mineral nutrients from the soil, forms the dry matter that is partitioned amongst the various plant organs (Lahav, 1996). The measurements of the total global radiation above and below the abaca canopy per individual plant in each plot were conducted from September 2003 to April 2004 at different time interval by using a light sensor. The readings were taken between 9:00-10:00am, 11:00am-12:00pm, and 14:00-15:00pm.

\section{Abaca-coconut agroecosystem}

The orientation of the coconut's long leaves at the top of the trunk, with the structure of leaves resembling Venetians blinds, permit part of the solar radiation incident on the foliage to pass through the lower profiles and the grounds. In this investigation, the irradiance availability below the coconut canopy and below the abaca canopy in different plots varies considerably (Figure 1). This is probably due to the differences on the number of coconuts (shade plant) between the plots, differences on leaf angle of coconuts and abaca plants, changes in spectral distribution of radiation through the canopy, multiple reflections of radiation within the canopy and the arrangement of leaves.

According to Nair (1979), the high reflectance of the thick-cuticled coconut leaves and the position of leaflets cause shattering of incident radiation in all directions. As a result, the light intensity at the plantation floor, even directly under the canopy shade of coconuts, could be higher than would be expected, and maybe sufficient for the growth of some plant species. Furthermore, the result from the field measurements confirmed that clouds further contributed this variability. The results also show that plants received high irradiance in both above and below abaca canopy at 14:00pm.

On the other hand, the computation of the light transmission ratio shows that the LTR1 (below the coconut or above the abaca canopy) and LTR2 (below the abaca canopy) are 33\% and 11\%, respectively (Figure 2). Moreover, Nair (1979) reported that the magnitude of radiation transmitted and the shade cast by the coconut canopy vary depending upon the age of palms. According to the study of Nelliat et al. (1974) on light availability in coconuts, when palms are about 8-10 years old, the percentage of sunlight transmitted is only about $20 \%$ and this remains almost constant until the palms are about 25 years of age.

Subsequently, the percent light transmission increases progressively and the canopy coverage of ground decreases inversely. By the time the palms are about 40 years old, the light transmission increases to about 50\%. This high transmission 
through the canopy of older palms is caused by the position of leaves and height of trunk. Nair (1979) explained, as the palms get older, about a third of the total number of leaves in the crown bend downward, whereas in the younger palms, the leaf reaches only an angle up to $90^{\circ}$ before it ripens and sheds off. The dropping of leaves will intercept less radiation and may probably reflect more light to the ground, than the horizontal or upright leaves (Nair, 1979). Likewise, as the trunk height increases, the magnitude of slant rays falling to the ground increases.
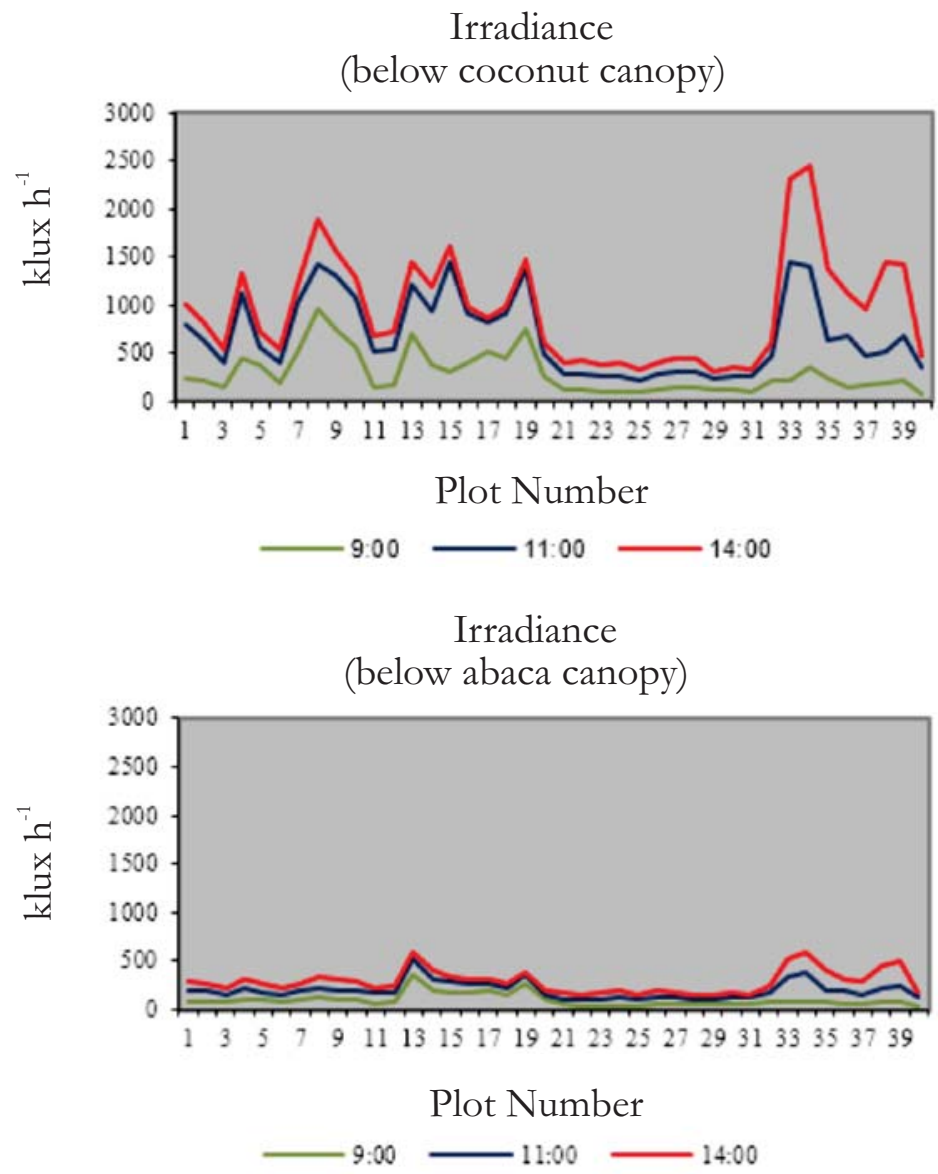

Fig. 1. Average daily light infiltration measurements in different study plots of the abaca-coconut agroecosystem.

\section{Abaca-Rainforestation agroecosystem}

In the Abaca-Rainforestation agroecosystem, the irradiance availability above and below the abaca canopy also varies significantly (Figure 3 ). This is probably due to the differences on the number of shade trees between the plots, differences on leaf angle of the shade trees and abaca plants, changes in spectral distribution of radiation through the canopy, multiple reflections of radiation within the canopy and the arrangement of leaves. Nobel and Long (1985) reported that absorption of photosynthetically active photon (PAR) flux by the canopy depends on leaf angle, sun elevation in the sky, the finite width of the sun's disc, changes in spectral 
distribution of PAR through the canopy, multiple reflections of PAR within the canopy and the arrangement of leaves in the canopy.

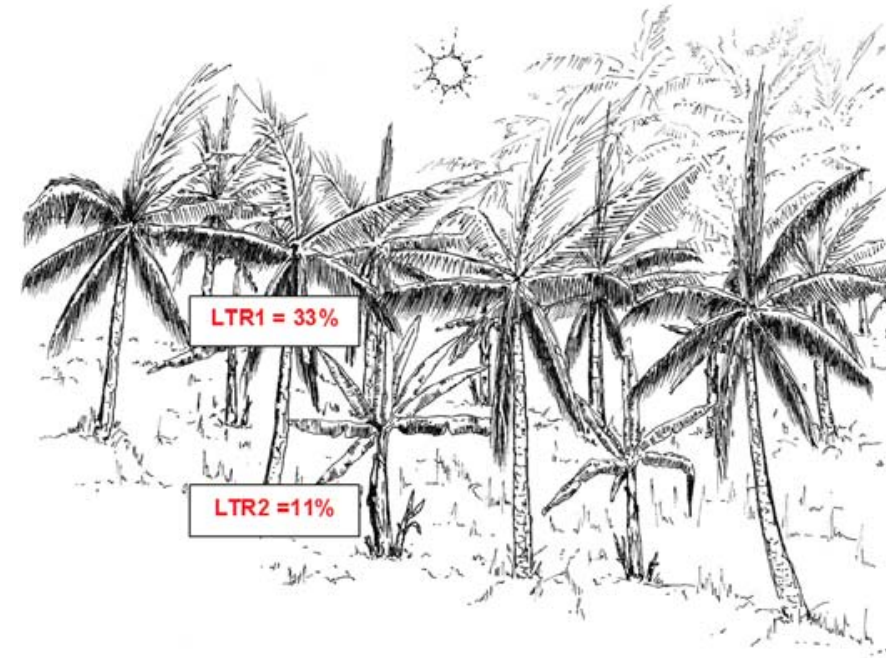

Fig. 2. Light transmission ratio (LTR) above and below the abaca canopy in abaca-coconut agroecosystem.

Irradiance

(below coconut canopy)
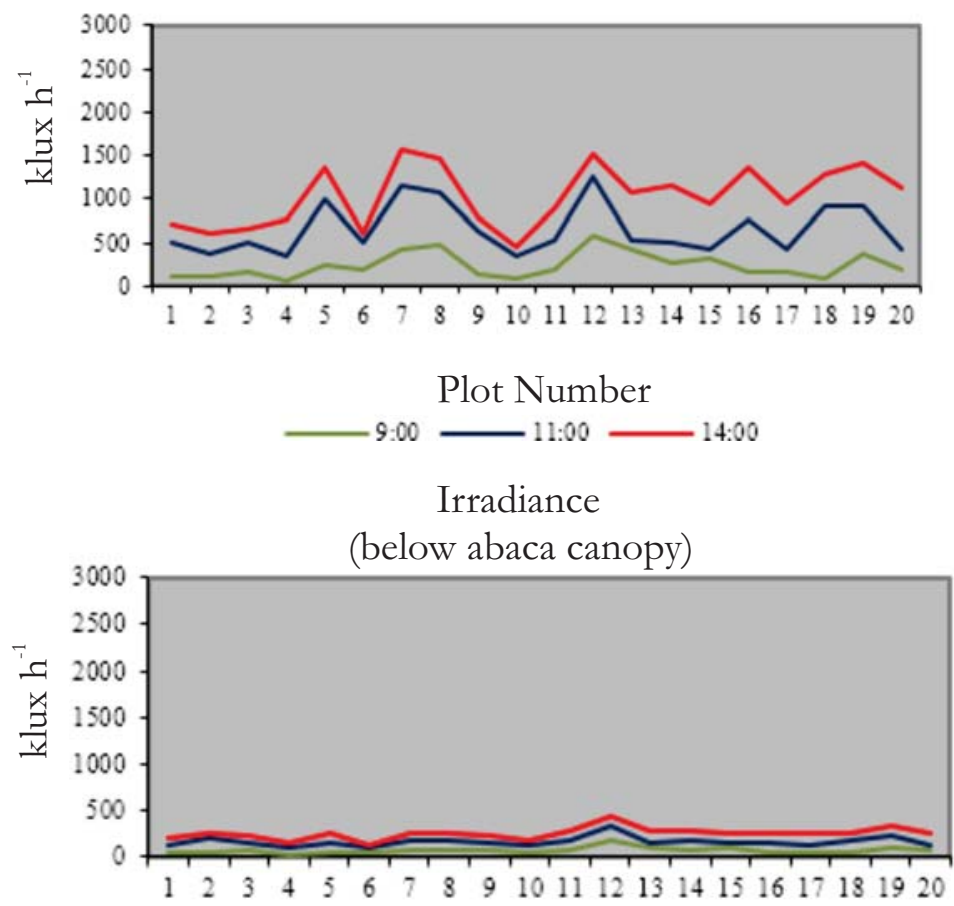

Plot Number

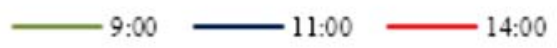

Fig. 3. Average daily light infiltration measurements in different study plots of the abaca-rainforestation agroecosystem. 
Furthermore, it was observed that the amount of clouds during the measurement considerably affects the reading that leads to variability of results. Finally, the results from the computation of the light transmission ratio show that LTR 1 is 36\% (above the abaca canopy) and LTR2 is 9\% (below the abaca canopy). Figure 4 shows the light transmission ratio under Abaca-Rainforestation integration.

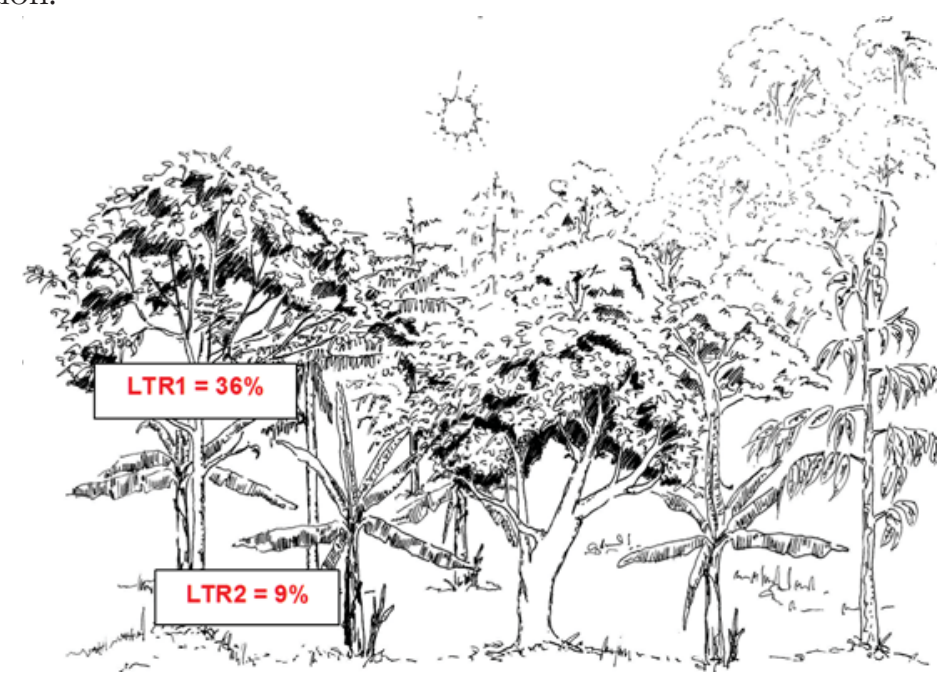

Fig. 4. Light transmission ratio (LTR) above and below the abaca canopy in Abaca-Rainforestation agroecosystem.

\section{Morphologicalperformance of abacaplants under the different multi-strata agroecosystems}

Monthly morphological growth parameters were monitored in the two study sites for the period September 2003 until April 2004. The following were measured: a) plant height, b) basal diameter, c) leaf area, and d) number of functional leaves. The measurements of plant height and diameter started immediately after the abaca suckers were planted.

\section{Abaca-coconut agroecosystem}

During the farm establishment, the average height and diameter of the abaca suckers (as planting materials) were $100 \mathrm{~cm}$ and $6.7 \mathrm{~cm}$, respectively. Results show that after 1 month of planting, the average height was $114 \mathrm{~cm}$ with an average diameter of $4.6 \mathrm{~cm}$ (Figure 5). This means that the plants grow to an average height increment of $14 \mathrm{~cm}$ per month.

However, the plant girth shows an opposite trend (Figure 6). Instead of developing, it decreased to an average of $2.1 \mathrm{~cm}$ per month. This is probably attributed to the following factors: a) inability of newly planted suckers to cope with the evaporative demand due to the removal of roots and old leaves during planting, b) the newly developed or young leaves were not fully adapted to high radiation, c) inactive root system of the planting materials due to root damage caused during the separation from the mother plant which confirmed the work of Eckstein (1994) on the physiological responses of banana, and d) the short dry 
period after planting aggravated the decrease in physiological activity causing higher water use and lower dry matter production of abaca.

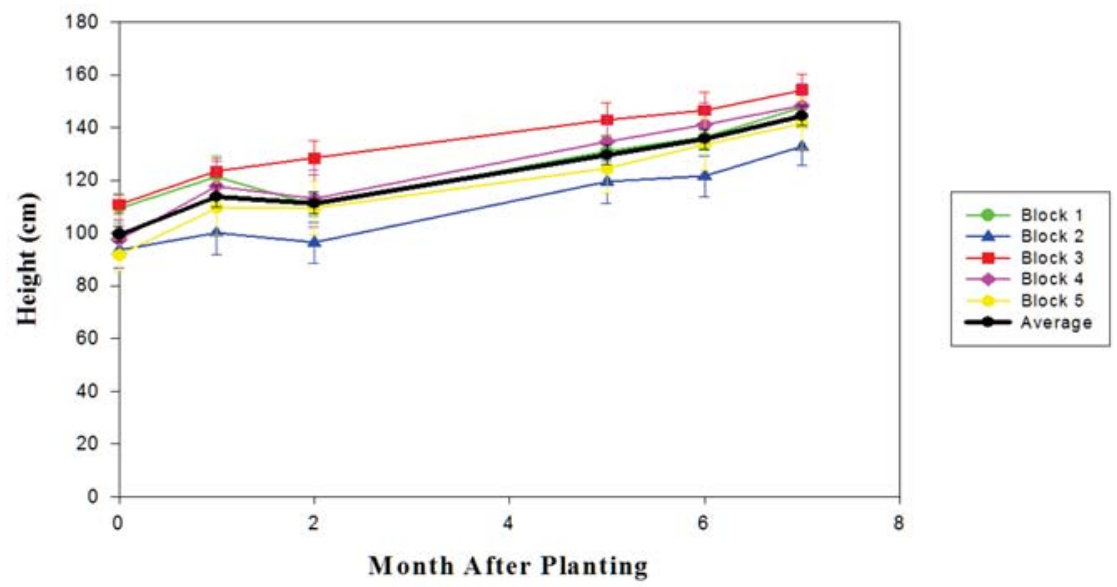

Fig. 5. Height increment of abaca planted at different blocks of the abaca-coconut agroecosystem.

Furthermore, after 2 months of planting, it was observed that both plant height and diameter continued to decline to an average of $111 \mathrm{~cm}$ and $4.0 \mathrm{~cm}$, respectively. This is attributed to the delay of new root growth and an efficient water uptake (Robinson and Bower 1988). A similar result was observed by Eckstein (1994) on the physiological responses of banana on different ontogenetic stage.

Finally, results further show that there was an increase in physiological activity after 5-7 months from planting. This is due to root regeneration and an increase in leaf emergence rate. Figure 7 presents the total number of functional leaves of abaca in different blocks of the abaca-coconut integration. The results show that there is a significant difference $(\mathrm{p} \leq 0.05)$ on the total number of functional leaves between blocks. The number of functional leaves increased from the $1^{\text {st }}$ to $6^{\text {th }}$ month and decreased after $7^{\text {th }}$ month from planting. This is due to the combined effects of different factors such as plant nutrition, wind speed, and mechanical damage caused by falling of coconut leaves either naturally or during copra harvesting. Thus, lead to the reduction of leaf sizes as well as the longevity of the leaf.

With regard to cumulative leaf area, results reveal a significant difference $(\mathrm{p} \leq 0.05)$ between blocks from the first to the seventh month after planting. There was an increase from the $1^{\text {st }}$ to $6^{\text {th }}$ month but a slight decrease after $7^{\text {th }}$ month from planting (Figure 8). The slight decrease in cumulative leaf area is due to the decline on the number of functional leaves which is due to the combined effect of nutrient deficiency, wind speed, and mechanical damage during copra harvesting. Hence, the pooled effect of the aforementioned factors led to the reduction of leaves sizes as well as the longevity of the leaf which explains the reduction of cumulative functional leaf area in different bocks overtime. 


\section{Abaca-Rainforestation agroecosystem}

The average height and diameter of the abaca suckers during the time of planting were $99 \mathrm{~cm}$ and $6.7 \mathrm{~cm}$, respectively. Results reveal that plant height increased to an average of $116 \mathrm{~cm}$ and $123 \mathrm{~cm}$ after 1 and 2 months from planting, respectively. This corresponds to an average height increment of $17 \mathrm{~cm}$ during the first month and $7 \mathrm{~cm}$ on the succeeding month. On the other hand, plant girth decreased to an average of $4.9 \mathrm{~cm}$ on the first month and $4.4 \mathrm{~cm}$ on the second month after planting.

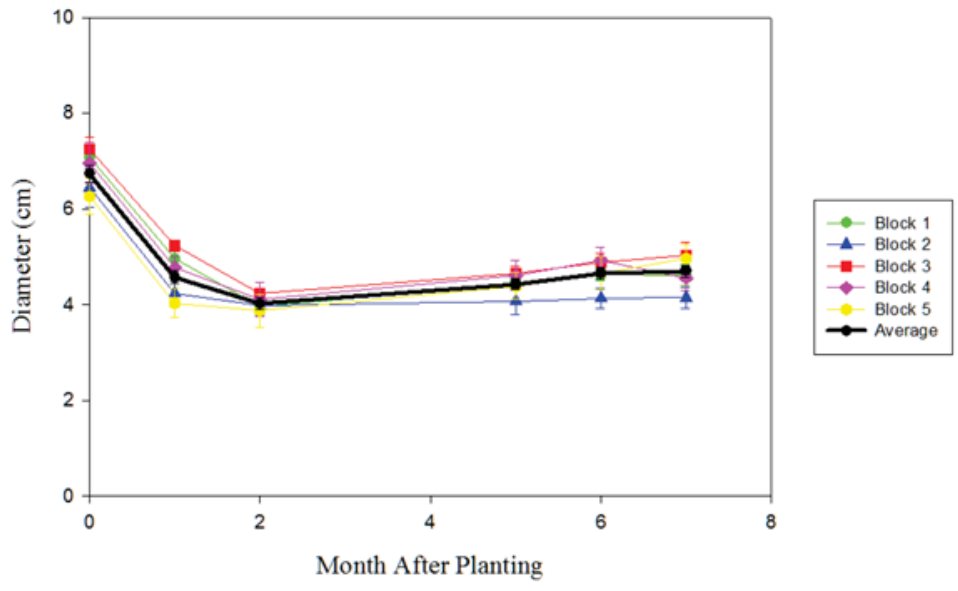

Fig. 6. Girth increment of abaca planted at different blocks of the abaca-coconut agroecosystem.

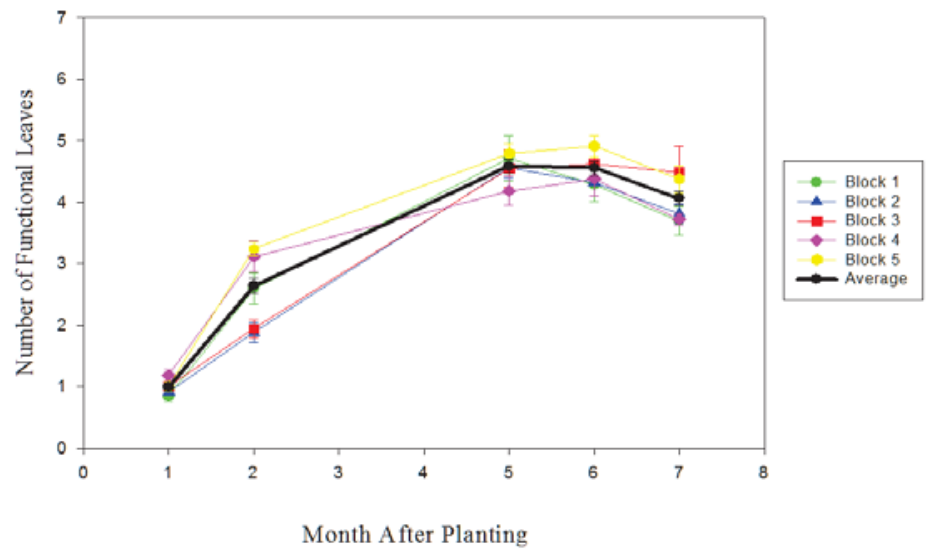

Fig. 7. Total number of functional leaves of abaca grown in different blocks of the abaca-coconut agroecosystem.

Meanwhile, Figures 9 and 10 show that there is a significant difference $(\mathrm{p} \leq 0.01)$ on plant height and girth between blocks. One month after planting, block 1 had an average height increment of $16 \mathrm{~cm}$ while block 4 had $22 \mathrm{~cm}$. Furthermore, block 1 continued to increase height (from $131 \mathrm{~cm}$ to $161 \mathrm{~cm}$ ) after 5 months from planting. However, block 4 shows a decline in height from $116 \mathrm{~cm}$ to $107 \mathrm{~cm}$. Furthermore, a different trend was observed in block 1 after 5-7 months 
from planting. The abaca plants started to increase girth on an average of $0.25 \mathrm{~cm}$ per month. This is due to root regeneration and an increase in leaf emergence rate which led to the development of an active root system and physiologically young leaf area. On the other hand, block 4 shows a continued decline of girth until the $7^{\text {th }}$ month from planting.

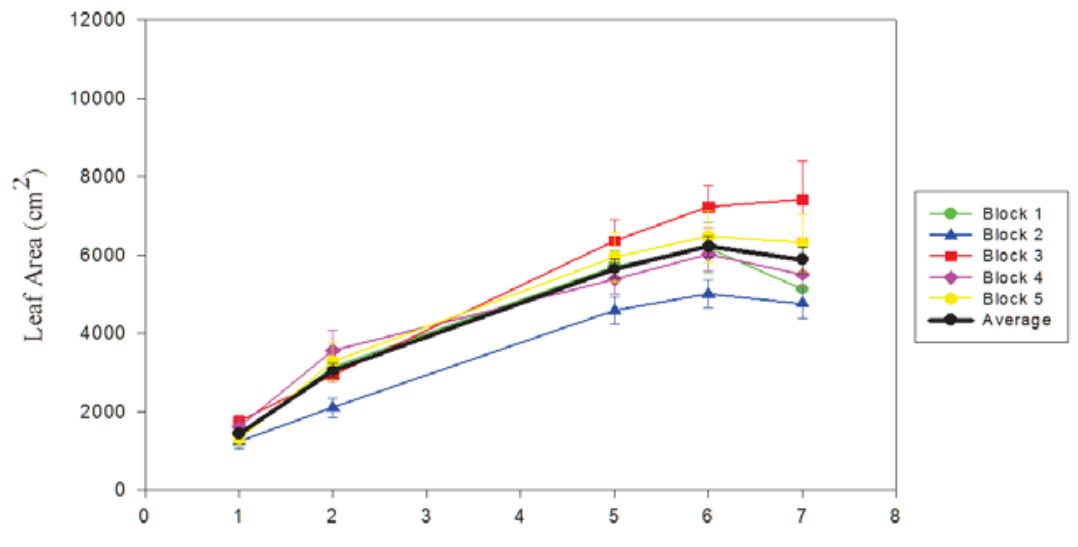

Month After Planting

Fig. 8. Functional leaf area of abaca planted in different blocks of the abaca-coconut agroecosystem.

Field observations show that lodging of leaves and even breaking of pseudostem due to high wind speed caused this decline in height. Likewise, based on the site topography, block 4 had a gradient of $67 \%$ and an elevation of 380 amsl while block 1 had 7\% and 326 amsl gradient and elevation, respectively. Hence, abaca plants in block 4 were exposed to extreme weather condition (i.e., wind speed) than blocks 1, 2 and 3. It was also observed that the number of shade trees and its corresponding sizes were few and smaller in block 4 compared to other blocks.

According to Simmonds (1959), wind speeds of 7-9 $\mathrm{m} \mathrm{s}^{-1}$ distort the crown when they are continuous such as in trade winds. Winds of about $18 \mathrm{~m} \mathrm{~s}^{-1}$ blow down large plants, especially those with bunch (Tabora, Jr. 1978; Green, 1963); therefore, causing both mechanical and physiological effects on the plants. Lahav (1996) explained that wind is responsible for the exchange of energy, in the form of momentum, and the gases (i.e. $\mathrm{CO}_{2}$ and water vapour) between the leaves and the atmosphere immediately above the crop. Hence, wind modifies the physiological functioning of the plant through its effect on the boundary layer and the temperature of the leaf (Lahav, 1996).

This can be explained according to the Penman-Monteith equation which describes the relationship between wind speed and evaporation (Monteith, 1973) that predict an increase in evaporation as wind speed increases. This explains higher water use and lower dry matter production of abaca leading to smaller leaf sheaths and diameter. Finally, the differences in nutrient availability between block 1 and block 4 further contributed to the continuous decline in girth.

Therefore, under such type of an abaca-based agroecosystem, it can be concluded that the morphological growth performance of abaca depends upon on the following factors: a) type of planting materials that exhibit fast recovery of its 
root system and increase in leaf emergence rate (e.g.. tissue cultured seedlings), b) plant nutrition, c) climatic and environmental factors (i.e., strong winds and pests), d) water availability during planting, and e) farm management and practices.

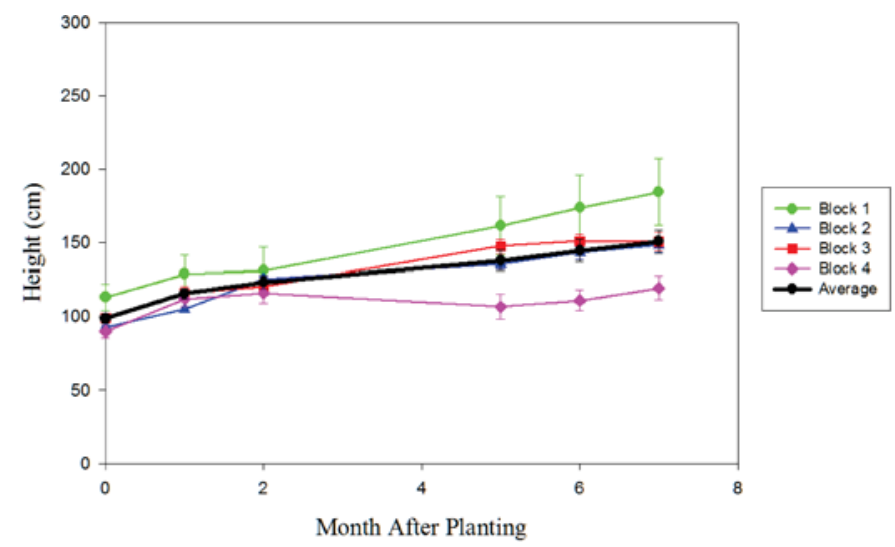

Fig. 9. Height increment of abaca planted at different blocks of the Abaca-Rainforestation agroecosystem

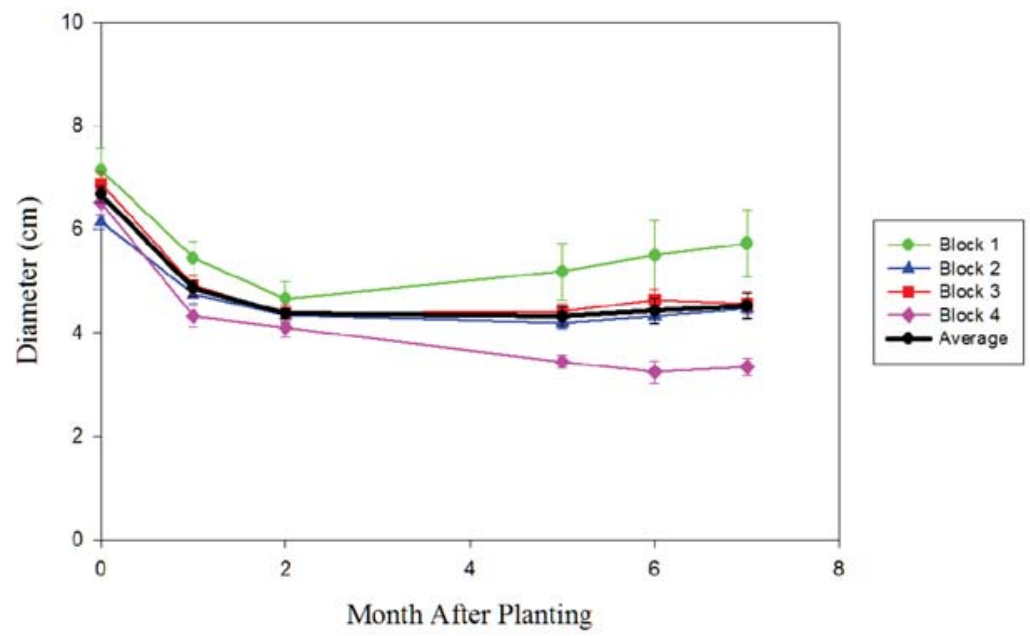

Fig. 10. Girth increment of abaca planted at different blocks of the Abaca-Rainforestation agroecosystem.

On the other hand, Figure 11 shows that block 1 has an average of 0.6 leaves per plant after one month from planting. However, after 7 -months from planting, results show that there was an increase in leaf emergence rate to an average of 5.3 leaves per plant. The same trend was noticed in block 4, where an average of 0.6 leaves per plant developed after one month and increased to 3.2 leaves per plant after 7 months from the date of planting. Statistical analysis result shows a significant difference $(\mathrm{p} \leq 0.05)$ on total number of leaves of abaca planted between blocks 5 to 7 month after planting.

According to Eckstein (1994), the increase in leaf emergence rate leads to an active root system and a high level of photosynthetic rate. Thus, the differences in the number of functional leaves between block 1 and 4 has an effect on the level of photosynthetic rate between blocks. Likewise, the formation and development 
of the leaves is dependent on light, temperature, plant nutrition, water availability and environmental factors, i.e., strong winds and pests (Garnica, 1997). All of these factors affect the morphological growth performance of abaca between blocks. Therefore, this explains their significant differences in the number of functional leaves.

Similarly, as can be seen in Figure 12, there is a high significant difference $(p \leq 0.01)$ on cumulative leaf area between blocks 1 and 4 . Results show block 1 had an average cumulative leaf area of $1184.91 \mathrm{~cm}^{2}$ after one month and increased to $10433.45 \mathrm{~cm}^{2}$ after 7 months from planting. Block 4, on the other hand, had $834.16 \mathrm{~cm}^{2}$ during the first month and $3005.22 \mathrm{~cm}^{2}$ after 7 months from planting. This means that block 1 had bigger and higher number of functional leaves compared to block 4. Again, this is attributed to the exposure of block 4 to high wind speed which led to tearing and breaking of leaves reducing the cumulative leaf area.

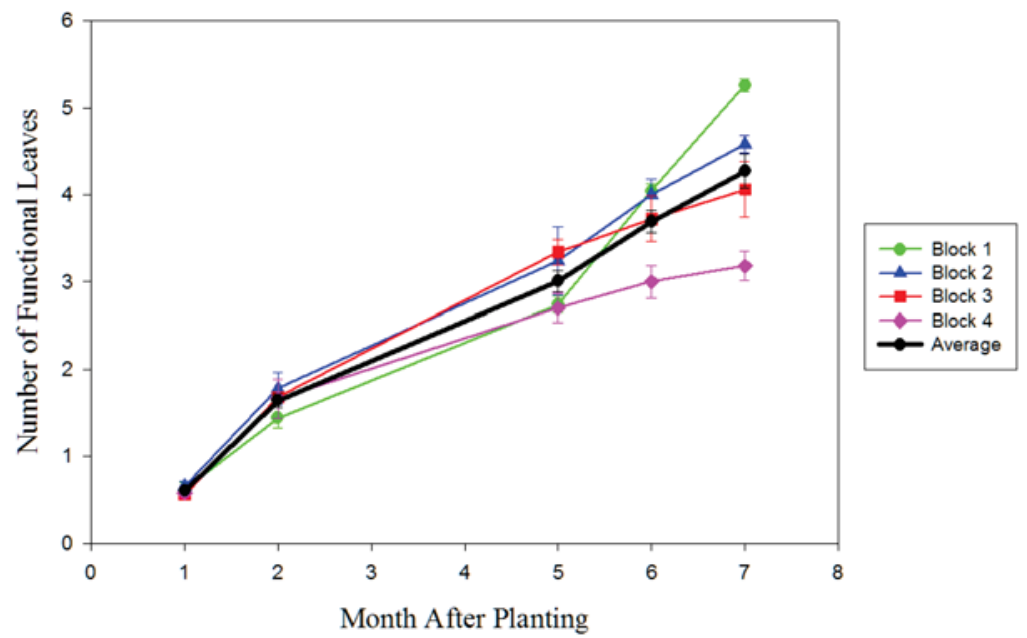

Fig. 11. Total number of functional leaves of abaca grown in different blocks of the Abaca-Rainforestation agroecosystem.

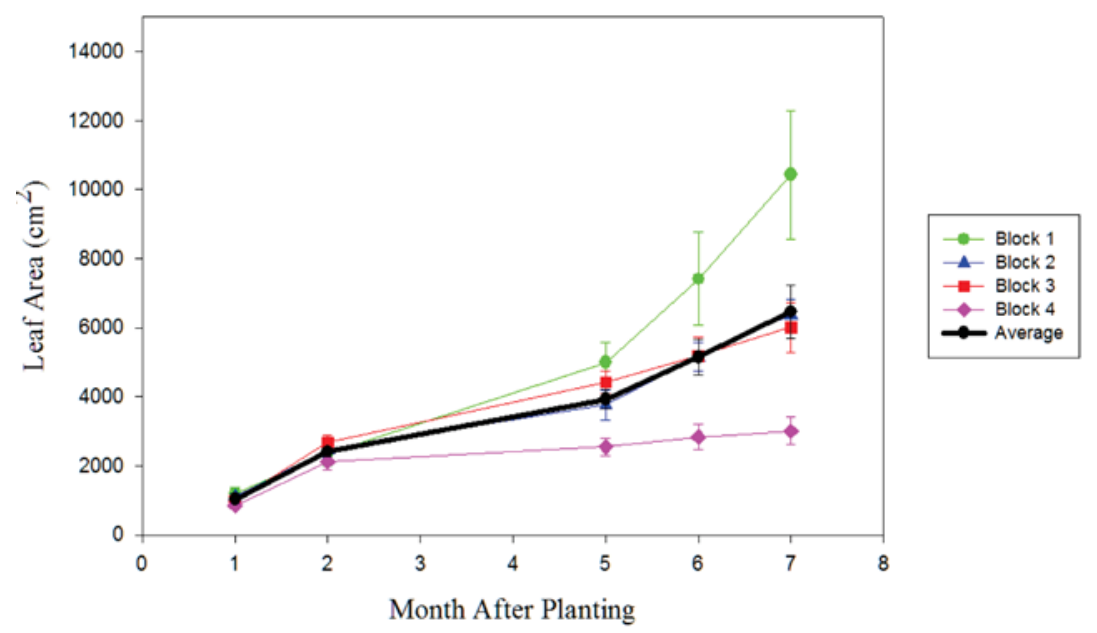

Fig. 12. Functional leaf area of abaca planted in different blocks of the Abaca-Rainforestation agroecosystem. 


\section{CONCLUSIONS}

The study investigated the best shade plant-abaca combinations (i.e., coconutabaca and tree-abaca) and its influence on light transmission ratio in relation to the abaca's morphological growth performance. Based on the results of this study, the following conclusions are generated:

The high reflectance of the thick-cuticled coconut leaves and the position of leaflets cause shattering of incident radiation in all directions. As a result, the light intensity at the plantation floor, even directly under the canopy shade of coconuts, is sufficient for the growth of abaca plants. However, the farmer should be more cautious during coconut harvesting to minimize mechanical damage on the leaves of the abaca plants that will significantly affect the morphological growth performance of the crop. On the other hand, in the Abaca-Rainforestation agroecosystem, irradiance availability was influenced by the number of shade trees, differences on leaf angle of the shade trees and abaca plants, changes in spectral distribution of radiation through the canopy, multiple reflections of radiation within the canopy and the arrangement of leaves.

Of the two multi-strata agroecosystems, it is concluded that Rainforestation appeared to be an effective approach in restoring the functions of an abaca-based agroecosystem by improving soil quality suitable for abaca fiber production. However, thinning or pruning the shade trees should be conducted to improve irradiance availability for better growth performance of abaca plants. Therefore, the tree-abaca under the Rainforestation system was the best combination. Nonetheless, the sustainability of such production system always lies on the hands of the farmer's, either to cut or harvest the trees or old coconut palms for lumber or to preserve them for ecological purposes by providing shade and wind breaks for the abaca plants.

Finally, due to high planting density in both types of abaca-based agroecosystems, fertilizer application and the use of high quality planting materials (i.e., tissue-cultured seedlings) that exhibit fast recovery of its root system and increase in leaf emergence rate are highly recommended. Likewise, topography and exposure to strong winds should be considered during site selection prior to abaca-based production system development.

\section{ACKNOWLEDGEMENT}

This study was funded by Eiselen-Foundation, Ulm and PPP Project on the Utilization of Abaca Fibers in the Automotive Industry. Likewise, the authors wish to thank Mr. Macario H. Romano and Mr. Noel Beray, landowners and farmer adopters, for giving them access to their farms and to Ms. Luz G. Asio for the soil and tissue analysis.

\section{REFERENCES}

AKHTER, N., M.M. RAHMAN, M. HASANUZZAMAN, and K. NAHAR. 2009. Physiological response of garden pea (Pisum sativum L.) grown under different light environment. Botany Research International 2(4), 304-309. 
ALLEN, C.B., R.E. WILL, R.C. MCGARVEY, D.R. COYLE, and M.D. COLEMAN. 2004. Radiation-use efficiency and gas exchange responses to water and nutrient availability in irrigated and fertilized stands of sweetgum and sycamore. Tree Physiology 25, 191-200.

ARMECIN, R.B., and F.M. GABON. 2008. Biomass, organic carbon and mineral matter contents of abaca (Musa textilis Neè) at different stages of growth. Industrial Crops and Products 28, 340-345.

ARMECIN, R.B., W.C. COSICO, and R.B. BADAYOS. 2011. Characterization of the different abaca-based agro-ecosystems in Leyte, Philippines. Journal of NaturalFibers 8, 111-125.

ASIO, V.B 1996. Characteristics, weathering, formation and degradation of soils from volcanic rocks in Leyte, Philippines. Hohenheimer Bodenkundliche Hefte 33, Germany

ASIO, V.B., R. JAHN, K. STAHR, and J. MARGRAF. 1998. Soils of the tropical forests of Leyte, Philippines II: impact of different land uses on status of organic matter and nutrient availability, in: Schulte, A., Ruhiyat, D., (Ed.), Soils of tropical forest ecosystems: characteristics, ecology and management, Springer, Berlin, pp. 37-44

BALSTER, N.J., and J.D. MARSHALL. 2000. Eight-year responses of light interception, effective leaf area index, and stemwood production in fertilized stands of interior Douglas-fir (Pseudotsuga menziesii var. glauca). Can. J. For. Res. 30, 733-743.

BANDE M.B., J. GRENZ, V.B. ASIO, and J. SAUERBORN. 2012. Nutrient uptake and fiber yield of abaca (Musa textilis var. Laylay) as affected by shade, irrigation and fertilizer application. Annals of Tropical Research. 34(1)124(2012).

BANDE M.B., J. GRENZ, V.B. ASIO, and J. SAUERBORN. 2013a. Fiber yield and quality of abaca (Musa textilis var. Laylay) grown under different shade conditions, water and nutrient management. Industrial Crops and Products. 42 (2013) 70-77.

BANDE M.B., J. GRENZ, V.B. ASIO, and J. SAUERBORN. 2013b. Morphological and physiological response of Abaca (Musa textilis var. Laylay) to shade, irrigation and fertilizer application at different stages of plant growth. International Journal of AgriScience. 3(2), 157-175.

BATUGAL, P.A., P. TABORA JR., L.O. NAMUCO, and J.U. SAJISE. 1977. Response of abaca to shading. NSDB Tech J 4(1), 61-64.

BJÖRKMAN, O., and P. HOLMGREN. 1966. Photosynthetic adaptation to light intensity in plants native to shaded and exposed habitats. Physiol. Plant. 19, 854889.

BOARDMAN, N.K. 1977. Comparative photosynthesis of sun and shade plants. Ann. Rev. Plant Physiol. 28, 355-377.

COOMBS, J. 1985. Techniques in Bioproductivity and Photosynthesis $2^{\text {nd }}$ Edition. Pergamon Press, Oxford.

COPELAND, E.B. 1911. Abaca. The Philipp Agricltrst Forester 1, 70-78.

DARGANTES, B.B. 1996. Socio-ecological case studies on forest lands cultivation in Leyte, Philippines. PLITS 1996/14(2) Germany

DEPARTMENT OF ENVIRONMENT and NATURAL RESOURCES. 1997. Sustainable livelihood options for the Philippines. Upland Ecosystem Information Kit. Quezon City, Philippines 
DURIYAPRAPAN, S., and E.J. BRITTEN. 1982. The effects of solar radiation on plant growth, oil yield and oil quality of Japanese mint. Journal of Experimental Botany 33(137), 1319-1324.

ECKSTIEN, K. 1994. Physiological Responses of Banana (Musa AAA: Cadavish subgroup) in the Subtropics. Inaugural Dissertation. Rheinischen FriedrichWilhelms-Universität Bonn, 203 pp.

FIBER DEVELOPMENT AUTHORITY. 2010. Statistical bulletin for the fiber industry 2008 edition. DA-FIDA, Quezon City, Philippines

GARNICA, A.M. 1997. Mineral Nutrient Deficiency in Plantain. Margraf Verlag, Germany, 112 pp.

GREEN, G.C. 1963. Fungi associated with crown rot of boxed bananas. Phytophatology, 271-275

HALOS, S.C. 2008. The abaca. Department of Agriculture, Quezon City, Philippines

HOLMGREN, P. 1968. Leaf factors affecting light-saturated photosynthesis in ecotypes of Solidago_virgaurea_from exposed and shaded habitats. Physiol. Plant. 21, 676-698.

ISAAC, M.E., V.R. TIMMER, and S.J. QUASHIE-SAM. 2007. Shade tree effects in an 8-year-old cocoa agroforestry system: biomass and nutrient diagnosis of Theobroma cacao by vector analysis. Nutrient Cycling in Agroecosystems, Springer Science-Business Media, B.V. 10705-006-9081-3

ISRAELI, Y., Z. PLAUT, and A. SCHWARTZ. 1994. Effect of shade on banana morphology, growth and production. Scientia Horticulturae 62, 45-56.

IUSS Working Group WRB (2006) World reference base for soil resources. World soil resources reports no. 103, FAO, Rome

JAHN, R., H.P. BLUME, V.B. ASIO and P. SCHAD. 2006. Guidelines for Soil Description (4th ed.). FAO, Rome.

KEMANIAN, A.R., C.O. STÖCKLE, and D.R. HUGGINS. 2004. Variability of barley radiation-use efficiency. Crop Sci. 44, 1662-1672.

LACUNA-RICHMAN, C. 2002. The Role of abaca (Musa textilis) in the household economy of a forest village. Small-scale forest economics, management and policy 1(1), 93-101.

LAHAV, E. 1996. Banana nutrition. In S. Gowen (ed). Banana and Plantains. Published by Chapman and Hall, 2-6 Boundary Row, London, SE1 8HN UK, 316: 258-316

MONTIENT, J.L. 1973. Principles of environmental physics. Edwards Arnold, London.

MORENO, L.O. 1994. Economic feasibility of intercropping selected abaca variety with annual crops in flat open lands. The Philipp J Crop Sci. 19 (Suppl No. 1): $\mathrm{S} 12$

NAIR, P.K.R. 1979. Intensive multiple cropping with coconuts in India, Principles, programmes and prospects. Advances in Agronomy and Crop Science. Verlag Paul Parey, Berlin und Hamburg, 147 pp.

NELLIAT, E.V., K.V.A. BAVAPPA, and P.K.R. NAIR. 1974. Multistoreyed cropping - new dimension of multiple cropping in coconut plantation. World crops 26, 262-266

NOBEL, P.S., and S.P. LONG. 1985. Canopy structure and light interception. In: Coombs, J. et. al. (eds). Techniques in Bioproductivity and Photosynthesis $2^{\text {nd }}$ Edition. Pergamon Press, Oxford. 
RAVEH, E., S. COHEN, T. RAZ, D. YAKIR, A. GRAVA, and E.E. GOLDSCHMIDT. 2003. Increased growth of young citrus trees under reduced radiation load in a semi-arid climate. Journal of Experimental Botany 54(381), 365-373.

ROBINSON, J.C. and J.P. BOWER. 1988. Transpiration from banana leaves in the subtropics in response to diurnal and seasonal factors and high evaporative demand. Scientia Horticultura, 129-143

SAIFUDDIN, M., A.M.B. HOSSAIN, and O. NORMANIZA. 2010. Impacts of shading on flower formation and longevity, leaf chlorophyll and growth of Bongainvillea glabra. Asian Journal of Plant Sciences 9(1), 20-27.

SAS. 2003. The SAS Systems for Windows. SAS Institute, Inc. Cary, North Carolina, USA.

SCHACHTSCHABEL, P. 1992. Lehrbuch der Bodenkunde. Enke, Stuttgart.

SCHLICHTING, E., H.P. BLUME, and K. STAHR. 1995. Bodenkundliches Praktikum. (2. Auflage) Blackwell, Berlin, 295 pp.

SOIL CONSERVATION SOCIETY OF AMERICA 1982. Resource Conservation Glossary, third ed., SCSA, Iowa

SIEVERT, E.P. 2009. The Story of Abaca: Manila hemp's transformation from textile to marine cordage and specialty paper. Ateneo de Manila University Press, Quezon City, Philippines

SPENCER, J.E. 1953. The abaca plant and its fiber (Manila hemp). Econ Bot. 7(3), 195-213.

SIMMONDS, N.W. 1959. Ensete cultivation in the southern highlands of Ethiopia, a review on Tropical Agriculture, Trinidad, 302-7

STANHILL, G., and S. COHEN. 2001. Global dimming: a review of the evidence for a widespread and significant reduction in global radiation with discussion of its probable causes and possible agricultural consequences. Agricultural and Forest Meteorology 107, 255-278.

STOVER, R.H. 1984. Canopy management in Valery and Grand Nain using leaf area index and photosynthetically active radiation measurements. Fruits 39, 8993.

TABORA, P.C., Jr. 1978. Historical Background. In: The Abaca. International Documentation Center on Abaca, University of the Philippines at Los Baños Library College, Laguna, Philippines, 135 pp.

TABORA, P.C., and R. SANTOS. 1978. Soil and climate for abaca production. In: The Abaca. International Documentation Center on Abaca, University of the Philippines at Los Baños Library College, Laguna, Philippines, 63: 60-63

UMALI D.L, and J.L. BREWBAKER. 1956. Abaca and its improvement. The Philipp Agricltrst. 40 (5-6), 213-230. 